\title{
Variability in the Betula pollen concentrations in the atmosphere of six urban areas in Slovakia in 2018
}

\author{
Jana Ščevková1, Janka Lafférsová2, Jozef Dušička', Mária Tropeková1 \\ ${ }^{1}$ Comenius University, Faculty of Natural Sciences, Department of Botany \\ ${ }^{2}$ Department of Environmental Biology, Section for Pollen Monitoring and PIS, Public Health Office, \\ Banská Bystrica, Slovakia
}

\begin{abstract}
:
Betula pollen is one of the most important aeroallergens during the spring months in the central European countries. In 2018, pollen monitoring was conducted in six urban areas (Bratislava, Banská Bystrica, Košice, Nitra, Trnava, and Žilina) in Slovakia. Investigations were carried out using a volumetric Hirst-type pollen trap (Burkard). Betula pollen season timing was determined by the $90 \%$ method when the start and end of the season were defined as the date when $5 \%$ and $95 \%$, respectively of the total pollen sum was reached. The pollen season start date was recorded

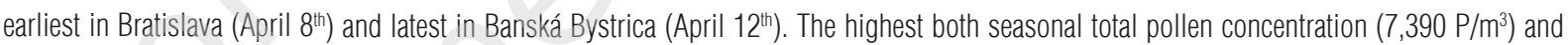
birch pollen allergen risk were found in Banská Bystrica. The shortest pollen season was recorded in Žilina (13 days) and the longest in Košice (25 days). Peak daily pollen concentrations ranged between $1,567 \mathrm{P} / \mathrm{m}^{3}$ in Žilina and $202 \mathrm{P} / \mathrm{m}^{3}$ in Košice.
\end{abstract}

Key words: pollen season, birch, aeropalynology, pollinosis

\section{Introduction}

The number of people suffering from allergies to pollen grains is constantly increasing [1]. According to the office of medical information and statistics of the Slovak Republic, the number of patients with allergic rhinitis increased by 100,000 between the years 2005 and 2008. Such phenomena can be caused by lifestyle changes, air pollution, but also by an increase in the amount of allergenic pollen in the air due to recent climate change [2].

In Central Europe, as well as in most other northern hemisphere countries, Betula pollen is considered as the most allergenic tree pollen allergen [1]. Similarly, Hrubiško [3] confirms that Betula pollen is one of the strongest allergens in Slovakia. Betula is also characterized by a high degree of cross-reactivity with other taxa, such as Alnus, Carpinus, Corylus, Salix, Tilia, Quercus, Fagus, Fraxinus, Ulmus, Juglans, Sambucus, Pinus, Populus, Platanus, Robinia, Aesculus, Acer, Eleagnus and Ligustrum [3].

In Slovakia, the genus Betula is represented by the species Betula pendula, B. pubescens, and $B$. nana. In terms of allergenic pollen production, the first species is of the greatest importance. Betula pendula is an essential pioneer tree with wide ecological amplitude, is a component of almost all woodland communities [4] and is often planted as an ornamental tree in urban areas [5]. It is a wind-pollinated monoecious tree with flowers grouped in lambs that grow 1-3 at the end of the branches. 
In Central Europe, birch trees bloom in full spring (late April to early June). In warm sunny weather, it takes 2-4 days to release the pollen from the anthers (dusting). Trees that grow at higher altitudes bloom later than those in the lowlands, so the time of birch pollen contamination may be even longer. It produces a large number of pollen grains with good aerodynamic properties, which can be transported over long distances [6]. Patients already experience allergic symptoms at a concentration of 80 pollen grains in $\mathrm{m}^{3}$ air [7], while at the peak of the season the average daily concentration can reach several thousand pollen grains in $\mathrm{m}^{3}$ of air $[8,9]$.

\section{Aim}

This present study aimed to compare Betula pollen seasons in 2018 in six urban areas situated in different parts of Slovakia.

\section{Materials and methods}

The aeropalynological study was carried out at six monitoring sties in Slovakia (Bratislava, Banská Bystrica, Nitra, Trnava, Košice and Žilina) in 2018. Bratislava, Nitra and Trnava are situated in the western part of the country in the Podunajská nížina Lowland, Košice in the eastern part in the Východoslovenská nížina Lowland, Banská Bytrica in the uplands in Central Slovakia, and Žilina in the uplands in northern part of Slovakia (fig. 1). Table 1 shows the geographic characteristics of the monitoring sites.

Figure 1. Locations of pollen monitoring stations in Slovakia.

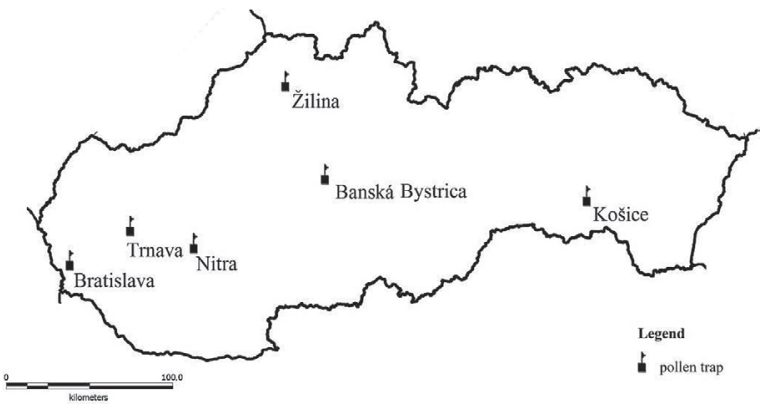

Pollen sampling was performed using a Hirst-type 7-day volumetric pollen trap (Burkard Manufacturing Co Ltd.). The methodology used was performed according to the standard method adopted by the British Aerobiology Federation [10]. Betula pollen grains were counted in 4 longitudinal traverses (except for Bratislava, where 12 transversal traverses were
Table 1. Geographical characteristics of the monitoring sites.

\begin{tabular}{|c|c|c|c|}
\hline Site & $\begin{array}{l}\text { Geographical } \\
\text { location }\end{array}$ & $\begin{array}{l}\text { Height } \\
\text { above sea } \\
\text { level (m) }\end{array}$ & $\begin{array}{l}\text { Height of pollen } \\
\text { trap above } \\
\text { ground level (m) }\end{array}$ \\
\hline Bratislava & $48^{\circ} 08^{\prime} \mathrm{N}, 17^{\circ} 04^{\prime} \mathrm{E}$ & 167 & 18 \\
\hline $\begin{array}{l}\text { Banská } \\
\text { Bystrica }\end{array}$ & $48^{\circ} 44^{\prime} \mathrm{N}, 19^{\circ} 09^{\prime} \mathrm{E}$ & 368 & 12 \\
\hline Košice & $48^{\circ} 43^{\prime} \mathrm{N}, 21^{\circ} 15^{\prime} \mathrm{E}$ & 208 & 15 \\
\hline Nitra & $48^{\circ} 18^{\prime} N, 18^{\circ} 05^{\prime} \mathrm{E}$ & 167 & 14 \\
\hline Trnava & $48^{\circ} 22^{\prime} \mathrm{N}, 17^{\circ} 35^{\prime} \mathrm{E}$ & 146 & 18 \\
\hline Žilina & $49^{\circ} 21^{\prime} \mathrm{N}, 18^{\circ} 74^{\prime} \mathrm{E}$ & 342 & 13 \\
\hline
\end{tabular}

counted) under a light microscope at a magnification of $400 \times$. Pollen concentration was expressed as a number of pollen grains per cubic meter of air $\left(\mathrm{P} / \mathrm{m}^{3}\right)$.

Poaceae main pollen seasons (MPS) were established according to a method by Nilsson and Persson [11], which defines the MPS as the period from which the cumulative sum of the daily pollen concentrations reaches $5 \%$ of the annual total pollen until the time when the sum reaches $95 \%$ (tab. 2).

The sum of daily average Poaceae pollen concentrations during the MPS was expressed as the Seasonal Pollen Integral (SPIn).

\section{Results and discussion}

Betula pollen is present in the air of Slovakia between the end of March and the beginning of May, with the maximum pollination in April [8].

The characteristics of the Betula pollen seasons in Slovakia in 2018 are shown in the table 2. The Betula pollen season started earliest in Bratislava (April $8^{\text {th }}$ ) and the latest in Banská Bystrica (April 12 ${ }^{\text {th }}$ ), whereas the end dates of the pollen season occurred from April $23^{\text {th }}$ in Žilina to May $5^{\text {th }}$ in Košice. The longest pollen season was observed for Košice (25 days) and the shortest for Žilina (13 days) (tab. 2, fig 2, 3). In 2018, the birch pollen season in Bratislava was 5 days shorter compared to the long-term average (24 days) [8].

One of the most important environmental factors affecting the timing of the pollen season is the geographical location and topography of the area and the associated climate specificities. In the northern regions and at higher altitudes, the pollen season starts later than in the southern regions with lower altitudes due to the lower temperature balance [12]. Similarly, we observed that in the southwestern part of Slovakia (Bratislava, Trnava, Nitra) the birch pollen season 
Table 2. Characteristics of Betula pollen season in Slovakia in 2018.

\begin{tabular}{|c|c|c|c|c|c|c|}
\hline Characteristics & Bratislava & Banská Bystrica & Košice & Nitra & Trnava & Žilina \\
\hline Pollen season start & April $8^{\text {th }}$ & April $12^{\text {th }}$ & April $11^{\text {th }}$ & April 9th & April $9^{\text {th }}$ & April $11^{\text {th }}$ \\
\hline Pollen season end & April 25 & April $25^{\text {th }}$ & May $5^{\text {th }}$ & April 30 th & April 29th & April 23 $3^{\text {th }}$ \\
\hline Season length (days) & 18 & 14 & 25 & 22 & 21 & 13 \\
\hline Seasonal Pollen Integral $\left(\mathrm{P} / \mathrm{m}^{3}\right)$ & 2,400 & 7,390 & 2,052 & 2,897 & 5,848 & 7,000 \\
\hline Peak value $\left(\mathrm{P} / \mathrm{m}^{3}\right)$ & 579 & 1,287 & 202 & 327 & 1,383 & 1,567 \\
\hline Peak day & April 10 $0^{\text {th }}$ & April $14^{\text {th }}$ & April $18^{\text {th }}$ & April $10^{\text {th }}$ & April $12^{\text {th }}$ & April $13^{\text {th }}$ \\
\hline No. of days (pollen $>80 \mathrm{P} / \mathrm{m}^{3}$ ) & 9 & 16 & 14 & 15 & 9 & 15 \\
\hline
\end{tabular}

Figure 2. Mean daily Betula pollen concentrations in Bratislava, Nitra and Košice in 2018.

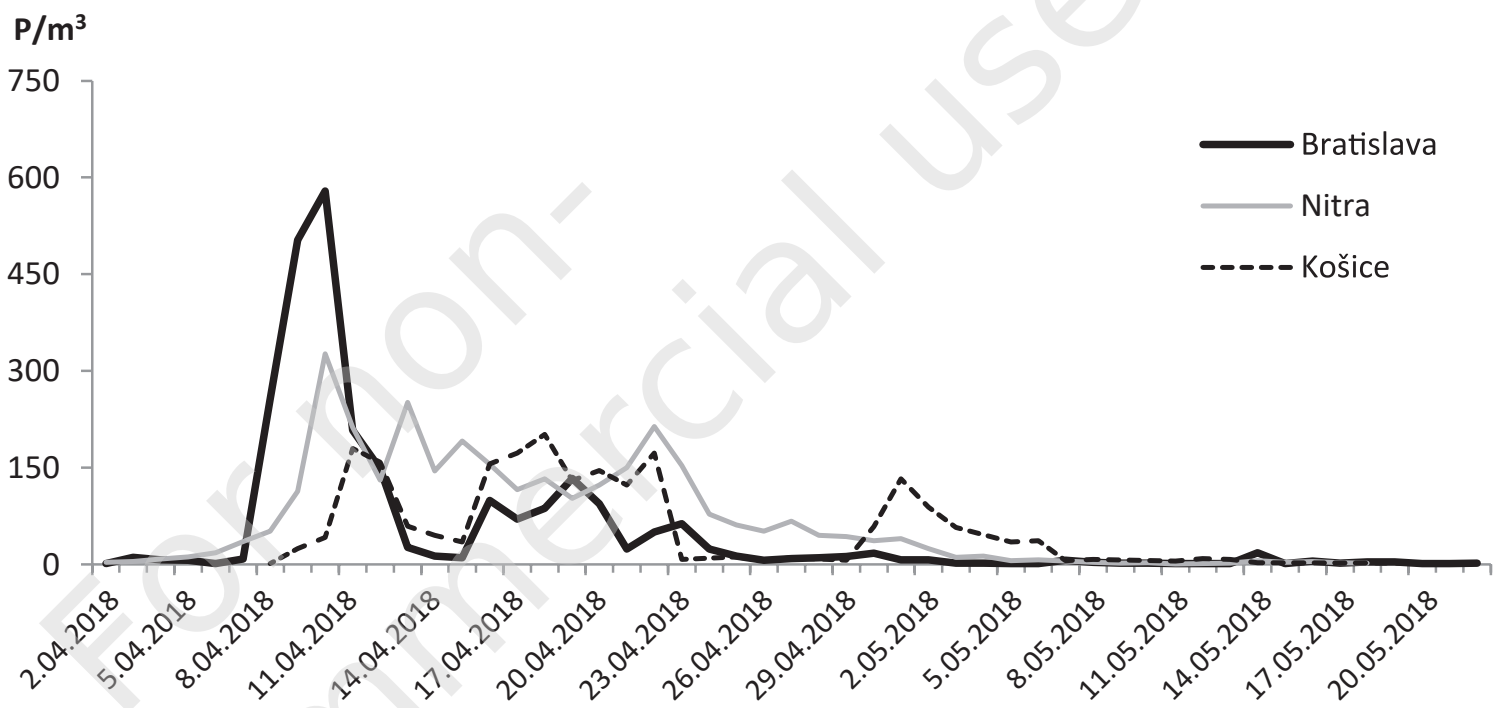

Figure 3. Mean daily Betula pollen concentrations in Banská Bystrica, Trnava and Žilina in 2018.

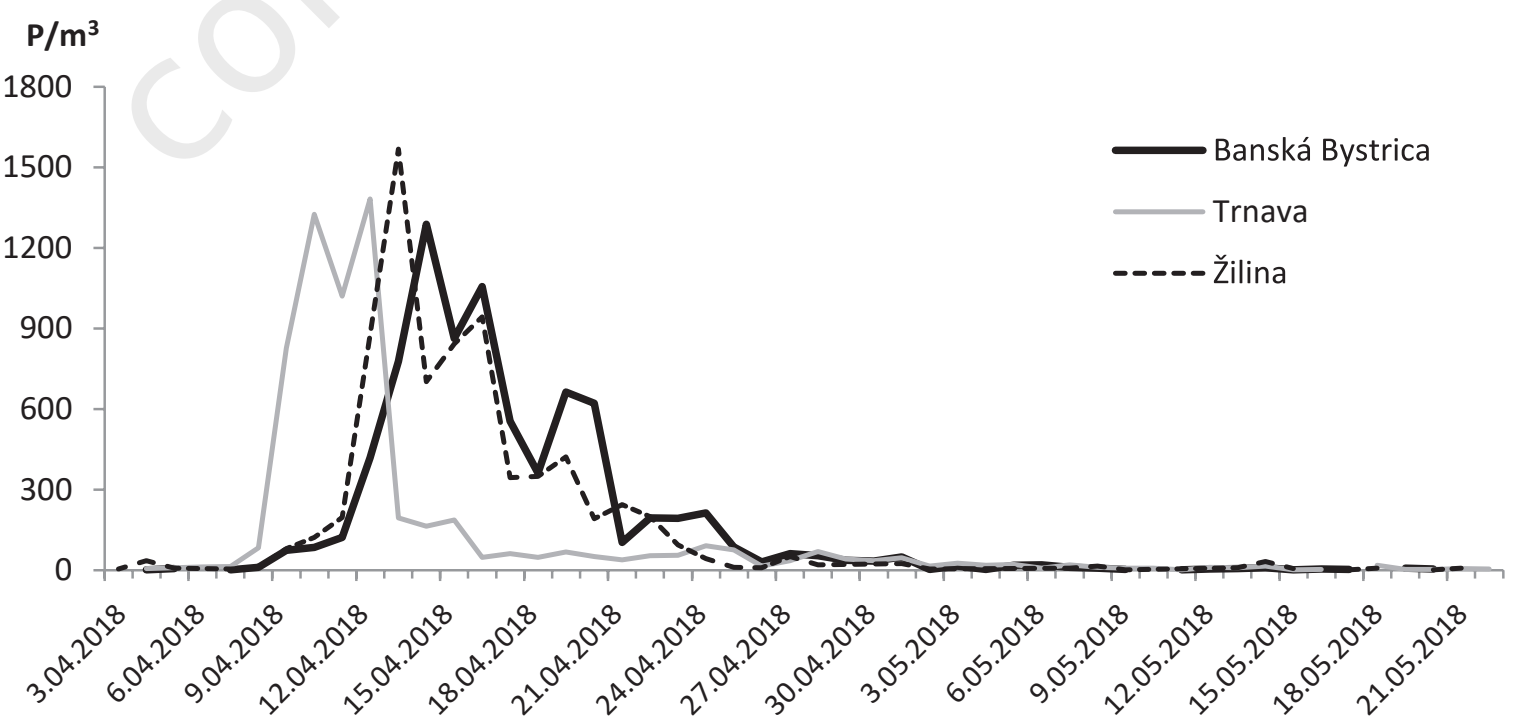

started several days earlier than in the northern and eastern regions of the country (tab. 2). Meteorological factors directly affect the flowering of birch trees. By their influence, the flowering period may be shortened or extended, or its beginning and/or end may be delayed. Increased air temperature, especially during the winter and spring months, due to recent climate change results in an early onset of plant flowering as well as an early start of the aerospore seasons [13, 14]. However, no significant shift has been observed in pollen season timing compared to the long-term period 2002-2009 from Bratislava [8]. 
The highest SPIn was recorded in Banská Bystrica $\left(7,390 \mathrm{P} / \mathrm{m}^{3}\right)$, while the lowest SPIn was noted in Košice (2,052 P/m $\mathrm{m}^{3}$ ) (tab. 2). A relatively high SPIn was also recorded in Trnava $\left(5,848 \mathrm{P} / \mathrm{m}^{3}\right)$. In Bratislava, the SPIn was $2,400 \mathrm{P} / \mathrm{m}^{3}$ which is much less compared to the long-term average $\left(8,557 \mathrm{P} / \mathrm{m}^{3}\right.$ - mean 2002-2009). However, it should be noted that birch is cyclically alternated for years with high and low pollen production due to their biological rhythms [8].

In 2018, maximum daily pollen concentrations ranged between $1,567 \mathrm{P} / \mathrm{m}^{3}$ in Žilina and $202 \mathrm{P} / \mathrm{m}^{3}$ in Košice (tab. 2, fig. 2, 3). Our study reveals that the peak dates occurred between April $10^{\text {th }}$ and April $18^{\text {th }}$. At all the monitoring sites, the number of Betula pollen grains on peak days exceeded the threshold value for sensitization, which is considered to be $80 \mathrm{P} / \mathrm{m}^{3}$ [7]. The number of days when the mean daily pollen concentration exceeds the threshold of sensitivity ranged between 9 days (Bratislava, Trnava) and 16 days (Banská Bystrica) (tab. 2).

\section{Conclusions}

1. In 2018, the Betula pollen season in Slovakia started between April $8^{\text {th }}$ (Bratislava) and April $12^{\text {th }}$ (Banská Bystrica). The length of the pollen season was 13-25 days (on average 19 days).

2 . The maximum daily pollen concentrations were recorded in Žilina and Trnava, while the lowest concentrations were noted for Košice.

3. In Banská Bystrica and Žilina, the highest SPIn was recorded, whereas the lowest SPIn was found in Košice.

4. The highest birch pollen allergen risk occurred in Banská Bystrica, Žilina, and Nitra.

\section{References}

1. D'Amato G, Cecchi L, Bonini $S$ et al. Allergenic pollen and pollen allergy in Europe. Allergy. 2007; 62(9): 976-90.

2. Beggs PJ. Impacts of climate change on aeroallergens: past and future. Clin Exp Allergy. 2004; 34: 1507-13.

3. Hrubiško M. Polinóza - aktuálny problém aj v XXI. storočí. Čast' III: poradie a skrižené reaktivity alergénnych druhov stromov, tráv a bylin podla ich klinického významu/Polinose - actual problem also in XXI. Century. Part III: sequence and cross reactivity of allergen tree, grass and plant species by their clinical significance. Klinická Imunológia a Alergológia. 1998; 2: 9-17.

4. Hynynen J, Niemistö P, Viherä-Aarnio A et al. Silviculture of birch (Bitola pendula Roth and Bitola pubescens Ehrh. In Northern Europe. Forestry. 2010; 83(1): 103-19.
5. Skjøth CA, Sommer J, Brandt J et al. Copenhagen - a significant source of birch (Bitola) pollen? Int J Biometeorol. 2008; 52(6): 453-62

6. Sofiev M, Siljamo P, Ranta $H$ et al. Towards numerical forecasting of long-range air transport of birch pollen: Theoretical considerations and a feasibility study. Int J Biometeorol. 2006; 50: 392-402.

7. Piotrowska-Weryszko K, Weryszko-Chmielewska E. Plant pollen content in the air of Lublin (central-eastern Poland) and risk of pollen allergy. Ann Agric Environ Med. 2014; 21(4): 693-96

8. Ščevková J, Dušička J, CHrenová J et al. Annual pollen spectrum variations in the air of Bratislava (Slovakia): years 2002-2009. Aerobiologia. 2010; 26: 277-87.

9. Grewling L, Jackowiak B, Nowak $M$ et al. Variations and trends of birch pollen seasons during 15 years (1996-2010) in relation to weather conditions in Poznań (western Poland). Grana. 2012; 51: 280-92.

10. British Aerobiology Federation. Airborne pollen and spores. A guide to trapping and counting. National Pollen and Hay fever Bureau, Rotherham 1995.

11. Nilsson S, Persson S. Tree pollen spectra in the Stockholm region (Sweden), 1973-1980. Grana. 1981; 20: 179-82.

12. Gehrig $R$, Peeters AG. Pollen distribution at elevations above $1000 \mathrm{~m}$ in Switzerland. Aerobiologia. 2000; 16(1): 69-74.

13. Galán C, Garca-Mozo H, Vázquez L et al. Heat requirement for the onset of the Olea europaea L. pollen season in several sites in Andalusia and the effect of the expected future climate change. Int J Biometeorol. 2005; 49(3): 184-8.

14. Ščevková J, Dušička J, Mičieta $K$ et al. The effects of recent changes in air temperature on trends in airborne Alternaria, Epicoccum and Stemphylium spore seasons in Bratislava (Slovakia). Aerobiologia. 2016; 32(1): 69-81.

ORCID

J. Ščevková - ID - http://orcid.org/0000-0002-3432-4105

Author's contributions:

Ščevková J.: writing the manuscript, proofreading; Laffersová J.: Banská Bystrica, Trnava, Žilina, Nitra, Košice aerobiological data; Dušička J.: Bratislava aerobiological data; Tropeková M.: Bratislava aerobiological data, work concept, literature review.

Copyright: @ Medical Education Sp. Z 0.0. This is an Open Access article distributed under the terms of the Attribution-NonCommercial 4.0 International (CC BY-NC 4.0). License (https://creativecommons.org/licenses/by-nc/4.0/), allowing third parties to copy and redistribute the material in any medium or format and to remix, transform, and build upon the material, provided the original work is properly cited and states its license.

Corresponding author:

Jana Ščevková, PhD, Assoc. Prof.

Comenius University, Faculty of Natural Sciences, Department of Botany 81102 Bratislava, Slovakia, Révová 39 tel. (+421) 254411541 e-mail: jana.scevkova@uniba.sk 